\title{
BOND BETWEEN GLULAM AND NSM CFRP LAMINATES
}

\author{
José Sena-Cruz $^{\text {a }}$, Marco Jorge ${ }^{b}$, Jorge M. Branco ${ }^{c}$, Vítor M.C.F. Cunha ${ }^{d}$ \\ ${ }^{a}$ Associate Professor, ISISE, Univ. of Minho, Dept. of Civil Engineering, Campus de Azurém, \\ 4810-058 Guimarães, Portugal. \\ Tel. +351 253510 200; Fax: +351253510217 \\ E-mail: jsena@civil.uminho.pt; Correspondinq author
}

${ }^{\mathrm{b}}$ Researcher, ISISE, Univ. of Minho, Dept. of Civil Engineering

E-mail: marco@civil.uminho.pt

${ }^{c}$ Assistant Professor, ISISE, Univ. of Minho, Dept. of Civil Engineering

E-mail: jbranco@civil.uminho.pt

${ }^{\mathrm{d}}$ Assistant Professor, ISISE, Dept. of Engineering, School of Science and Technology, University of Trás-os-Montes e Alto Douro, 5001-801 Vila Real, Portugal.

E-mail: vcunha@utad.pt

\begin{abstract}
With the aim of evaluating the bond behaviour between glulam and carbon fibre reinforced polymer laminates strips, an experimental program using pull-out tests was carried, when the near-surface strengthening technique is applied. Two main variables were studied: the bond length and the type of pull-out test configuration. The instrumentation included the loaded and free-end slips, as well as the pullout force. Based on the obtained experimental results, and applying an analytical-numerical strategy, the local bond stress-slip relationship was determined. In this work the tests are described, the obtained results are presented and analysed, and the applicability of an inverse analysis to obtain the local bond law is demonstrated.
\end{abstract}

Keywords: CFRP laminate; glulam; bond behaviour; NSM strengthening technique; local bond stressslip. 
Sena-Cruz, J.M.; Jorge, M.; Branco, J.; Cunha, V.M.C.F. (2012) "Bond between glulam and NSM CFRP laminates." Construction \& Building Materials, 40, 260-269.

\section{Introduction}

In the early $20^{\text {th }}$ century Friedrich Otto Hetzer proposed glued laminated (Glulam) timber elements by a strategic application of slender sawn timber pieces. He combined small section pieces, plentiful in the market, producing elements of almost unlimited size and overcoming some formal and technical limitations associated to timber construction. The restrictions on the use of steel in construction during the World War II also helped the development of this new product, which knew two great dated developments. First one was in 1940 with the emergence of the first synthetic glues, and the second was in 1980 with the normalization of the marketing of various products used in the construction industry, including the Glulam timbers.

Nowadays, there is a large variety of products derived from wood and each of them has its own specificities. Glulam timbers are perhaps the engineered wood product most widely used in construction sector, essentially due to both its mechanical properties and strict/industrialized manufacturing process. The defects of wood pieces used to produce Glulam material are eliminated or made irrelevant, leading to mechanical strength and modulus of elasticity higher than those of solid wood. Furthermore, its rigorous production results in very precise geometries and in highly controlled moisture content. Glulam allows the production of parts with the desired shape and length. Spans can be up to 40 meters and height of sections can go up to 2 meters, exhibiting an excellent strength to weight ratio and an excellent resistance to aggressive chemical environments. Due to these characteristics, Glulam materials have widely been used in transportation infrastructures, e.g. bridges, and in roofs of pavilions.

Fibre reinforced polymer (FRP) has been object of deep research, in order to confirm its capabilities on repairing and strengthening existing structures. The great confidence in this composite is grounded on its advantages such as: high stiffness and tensile strength, low weight, easy installation procedures, high durability (no corrosion), electromagnetic permeability and practically unlimited availability in terms of geometry and size.

Guides, such as the ACI 440.2R-08 [1], describe the most common strengthening techniques using this kind of composite, namely the externally bonded reinforcement (EBR) and near-surface mounted (NSM). Both these techniques are mainly applied in concrete structures however, it has emerged some experiences in timber structures. EBR is an older and further explored technique, but NSM has already proved its greater efficiency in the flexural and shear strengthening. De Lorenzis and Teng (2007) [2] 
Sena-Cruz, J.M.; Jorge, M.; Branco, J.; Cunha, V.M.C.F. (2012) "Bond between glulam and NSM CFRP laminates." Construction \& Building Materials, 40, 260-269.

describe some advantages of NSM over EBR, such as: the amount of in situ installation work may be reduced, as surface preparation other than grooving is no longer required (e.g., covering removal is not necessary; irregularities of the timber surface can be more easily accommodated); NSM reinforcement is less prone to debond from the substrate; NSM elements can be more easily anchored into adjacent members to prevent debond failures; NSM elements are protected by the wood cover and so they are less exposed to accidental impact and mechanical damage, fire, and vandalism; the aesthetic of the strengthened structure is virtually unchanged.

Studies that comprise the combination of strengthening solutions based on FRP's and NSM technique with timber structures (Borri et al. (2005) [3], Johnsson et al. (2006) [4], Ahmad (2010) [5]) are significantly less than studies based on interventions in concrete structures, but the results obtained to increase load carrying capacity and stiffness when the NSM technique is applied revealed good performance. The development of a research related with any strengthening technique should have special attention to bond behaviour; because this is a key point to the composite strengthening system having an excellent performance, in particular with regard to the ultimate load-carrying capacity of a reinforced element and some serviceability aspects.

Several test methods have been developed and proposed in last half of the XX century and used within the scope of the investigation, especially on the concrete material where the bending and direct pull-out tests are the most frequent. At present, there is no general agreement in which is the most suitable test set-up to evaluate the behaviour of the different FRP strengthening systems.

To study the bond behaviour between glulam and CFRP laminates, when the NSM strengthening technique is used, an experimental program composed of pull-out tests was carried out. The influence of the bond length and the type of pull-out test (direct or beam) on the bond behaviour was investigated. In the following sections the tests are described in detail, and the obtained results are presented and discussed. Using these results and applying an inverse analysis procedure, the local bond stress-slip relationship is derived. 
Sena-Cruz, J.M.; Jorge, M.; Branco, J.; Cunha, V.M.C.F. (2012) "Bond between glulam and NSM CFRP laminates." Construction \& Building Materials, 40, 260-269.

\section{Experimental program}

\subsection{Specimens and Test Configuration}

Forty validated pull-out bond tests composed the experimental program. The studied bond lengths ranged between 30 and $180 \mathrm{~mm}$ in order to assess its influence on the bond behaviour. The lower bond length value was set as $30 \mathrm{~mm}$ since the bond length must be large enough to be representative of the glulam-CFRP's interface conditions and to make negligible the unavoidable end effects. The upper bound was limited to $180 \mathrm{~mm}$ due to limitations associated to the specimen's geometry.

Fig. 1(a) shows the specimen's geometry and the adopted direct pull-out test configuration (DPT). The specimen consists of a glulam block sized $140 \times 200 \times 400 \mathrm{~mm}^{3}$, in which the CFRP strip is embedded. The bond test region was located in the upper part of the block, and several bond lengths, $L_{\mathrm{b}}$, were studied $(30,60,120$ and $180 \mathrm{~mm})$. To avoid a premature splitting failure in the glulam ahead the loaded-end, the bond length started $50 \mathrm{~mm}$ far from the block end. The instrumentation of the specimens consisted on three linear variable differential transducers (LVDT) and a load cell. The LVDT1 was used to control the test at $2 \mu \mathrm{m} / \mathrm{s}$ slip rate, and, to measure the slip at the loaded-end, $s_{1}$, while the displacement transducer LVDT2 was used to measure the slip at the free-end, $s_{\mathrm{f}}$. The LVDT3 was used to measure the rotation of the specimen. The applied force, $F$, was registered by a load cell placed between the specimen top surface and the actuator. The overall layout of the performed tests is presented in Fig. 1(b).

Fig. 2(a) shows the specimen geometry and configuration adopted for the beam pull-out tests (BPT). The specimen is composed by two glulam blocks (block A and B) of equal dimensions, $140 \times 200 \times 300 \mathrm{~mm}^{3}$, interconnected by a steel hinge located at mid-span in the top part, and also by the CFRP laminate fixed at the bottom. The bond test region was located in the bottom part of block A, and several bond lengths, $L_{\mathrm{b}}$, were analysed $(30,60,120$ and $180 \mathrm{~mm})$. Similarly to the DPT, the bond length started $50 \mathrm{~mm}$ far from the block end to avoid premature splitting failure in the glulam ahead the loadedend. The instrumentation of the beam tests consisted on the use of two LVDT's, a strain gauge and a load cell. The LVDT2 was used to control the test, at $2 \mu \mathrm{m} / \mathrm{s}$ slip rate, and simultaneously to measure the slip at the loaded-end, $s_{\mathrm{l}}$, while the LVDT1 was used to measure the slip at the free-end, $s_{\mathrm{f}}$. The applied force $F$ was registered by a load cell placed between the steel plate and the actuator. A strain gauge, placed at the mid-span of the specimen, measured the strains during the test (applied in one specimen per each series). 
Sena-Cruz, J.M.; Jorge, M.; Branco, J.; Cunha, V.M.C.F. (2012) "Bond between glulam and NSM CFRP laminates.” Construction \& Building Materials, 40, 260-269.

Code names given to the series consisted on alphanumeric characters separated by underscores.

The first string defines the type of pull-out test (DPT - direct pull-out test; BPT - beam pull-out test). The second string indicates the bond length in millimetres (e.g. Lb120 represents a specimen with a bond length of $120 \mathrm{~mm}$ ) and the last string designates the number of the specimen.

\subsection{Material characterization}

\subsubsection{Timber}

Glued laminated timber, currently named by glulam, of strength class GL24h (NP EN 1194:1999 [6]), was used for all the series. The material characterization of the GL24h included compressive and tensile tests parallel to the grain, according to EN 408 [7]. Sixteen specimens were used in each test type. From the compressive parallel to the grain tests, an average compressive strength of $28.0 \mathrm{MPa}$ with a coefficient of variation $(\mathrm{CoV})$ of $17.6 \%$, and an average modulus of elasticity of $6.6 \mathrm{GPa}(\mathrm{CoV}=27.8 \%)$ were obtained. From the tensile parallel to the grain tests, an average tensile strength, a modulus of elasticity and a strain at the peak stress of 55.9 MPa $(\mathrm{CoV}=16.7 \%), 9.2 \mathrm{GPa}(\mathrm{CoV}=11.9 \%)$ and $0.64 \%$ $(\mathrm{CoV}=12.4 \%)$ were obtained, respectively. The density and moisture content of the wood was assessed following the procedures included in ISO 3130:1975 [8] and ISO 3131:1975 [9], respectively. From the 54 specimens similar to the ones used in the pull-out tests and submitted at the same environmental conditions (laboratory environment), a density value of $418.1 \mathrm{~kg} / \mathrm{m}^{3}(\mathrm{CoV}=0.7 \%)$ and a moisture content of $7.4 \%(\mathrm{CoV}=3.8 \%)$ were obtained.

\subsubsection{CFRP laminate}

The CFRP laminate used in the present work, with $1.4 \mathrm{~mm}$ thick and $20 \mathrm{~mm}$ wide, and a trademark CFK 150/2000, was provided in rolls of 100 meters each, and was supplied by $\mathrm{S} \& \mathrm{P}^{\circledR}$ Clever Reinforcement Company. This laminate is composed of unidirectional carbon fibres, agglutinated by an epoxy adhesive and has a smooth external surface.

To assess the tensile properties of the CFRP laminate strip, seven tensile tests were carried out according to ISO 527-5:1997 [10]. Tests were performed under a displacement rate of $2 \mathrm{~mm} / \mathrm{min}$. To evaluate the modulus of elasticity, a clip gauge was mounted at middle region of each specimen. From the mechanical characterization a modulus of elasticity, a tensile strength and a strain at peak stress of 
Sena-Cruz, J.M.; Jorge, M.; Branco, J.; Cunha, V.M.C.F. (2012) "Bond between glulam and NSM CFRP laminates." Construction \& Building Materials, 40, 260-269.

161.8 $\mathrm{GPa}(0.9 \%), 2784 \mathrm{MPa}(\mathrm{CoV}=3.9 \%)$ and $1.7 \%(\mathrm{CoV}=3.0 \%)$, were obtained, respectively. For all specimens, the failure mode occurred in explosive way due to the fibre progressive rupture located at specimens' mid-height.

\subsubsection{Adhesive}

In the present experimental work the epoxy MapeWood Paste 140, supplied by MAPEI ${ }^{\circledR}$, was used. This thixotropic adhesive is currently used for the restoration of timber structural elements, and is composed of two premeasured parts (Part $\mathrm{A}=$ resin and Part $\mathrm{B}=$ hardener). To assess the mechanical properties of the hardened adhesive, tensile tests were carried out according to ISO 527-2:1993 [11]. After casted, the six specimens were kept in the laboratory environment in the vicinity of the pull-out specimens, and they were tested at the same age of the pull-out tests. The adhesive specimens were tested in a universal test machine, at a displacement rate of $1 \mathrm{~mm} / \mathrm{min}$. A clip gauge mounted on the middle zone of the specimen recorded the strains, whereas a high accurate load cell registered the applied force. From the tests an average tensile strength of $17.2 \mathrm{MPa}(\mathrm{CoV}=7.5 \%)$, modulus of elasticity of $8.1 \mathrm{GPa}$ $(\mathrm{CoV}=17.6 \%)$ and a strain at peak stress of $0.26 \%(\mathrm{CoV}=19.6 \%)$ were obtained.

\subsection{Preparation of specimens}

The preparation of the specimens required several steps, namely: cutting the glulam block; making the grooves; and, strengthening. Glulam blocks and the corresponding grooves were request to the wood supplier in order to assure very precise geometry of both. The adopted NSM strengthening procedures are quite well documented in the literature (De Lorenzis and Teng 2007 [2]; Barros et al. 2007 [12]) and specific detailed information related to the specimens used in the present work can be found elsewhere (Jorge 2010 [13]). After strengthening, the specimens were kept in the laboratory environment before being tested. The pull-out tests were carried out at least 10 days after the application of the CFRP reinforcement.

\section{Results and discussion}

Fig. 3 depicts the average pull-out force versus loaded-end slip $\left(F_{1}-S_{1}\right)$ relationships for all the tested series, whereas Tables 1 and 2 include the main results obtained on the direct and beam pull-out 
Sena-Cruz, J.M.; Jorge, M.; Branco, J.; Cunha, V.M.C.F. (2012) "Bond between glulam and NSM CFRP laminates." Construction \& Building Materials, 40, 260-269.

tests (DPT and BPT), respectively. In these tables $F_{\text {fmax }}$ is the maximum pull-out force; $F_{\mathrm{fu}}$ is the CFRP tensile strength (see also Section 2.2.2); $\tau_{\max , a v 1}$ and $\tau_{\max , a v 2}$ are the average bond stress at the laminateepoxy and glulam-epoxy interfaces, respectively, and are evaluated by $F_{\text {fmax }} /\left(P_{\mathrm{f}} L_{\mathrm{b}}\right)$ and $F_{\mathrm{fmax}} /\left(P_{\mathrm{g}} L_{\mathrm{b}}\right)$, where $P_{\mathrm{f}}\left(=2 \times w_{\mathrm{f}}+2 \times t_{\mathrm{f}}\right)$ is the perimeter of the CFRP cross-section and $P_{\mathrm{g}}\left(=2 \times h_{\mathrm{g}}+b_{\mathrm{g}}\right)$ is perimeter of the groove cross-section in contact with the adhesive, being $w_{\mathrm{f}}$ and $t_{\mathrm{f}}$ the width and the thickness of the CRRP and $h_{\mathrm{g}}$ and $b_{\mathrm{g}}$ the depth and width of the groove, respectively; $s_{\mathrm{fmax}}$ and $s_{\mathrm{lmax}}$ are the free-end and loadedend slips at $F_{\text {fmax }}$, respectively.

The pull-out force was directly evaluated by the values registered in the load cell for the case of direct pull-out test configuration. In the case of the beam pull-out tests, two distinct approaches were initially adopted (see Fig. 2): (i) the first one was based on the force values measured at the load cell and takes into account the internal lever arm, i.e., the distance between the longitudinal axis of the CFRP and the contact point at the steel hinge; (ii) the second approach is based on the values recorded by the strain gage glued to the CFRP rod and takes into account the corresponding modulus of elasticity and its cross sectional area. No significant differences were found between both approaches (see Jorge 2010 [13]) so, only the first approach was adopted in the present work.

In the direct pull-out tests the records registered by the LVDT1 (see Fig. 1) include not only the loaded-end slip, $s_{1}$, but also the elastic deformation of the CFRP between the loaded-end section and the top surface of the timber block (50 mm of distance). In the present analysis only the $s_{1}$ was considered. For that purpose the modulus of elasticity referred in Section 2.2.2 was taken into account.

In general, the $F_{1}-S_{1}$ responses are characterized by an almost linear branch up to the peak load. For both type of pull-out tests, the maximum pull-out force and the corresponding loaded-end slip increase when the bond length increases. When the type of test is compared, beam pull-out tests yielded a superior performance, not only in terms of higher peak load, but also a more ductile response, since the $F_{1}-S_{1}$ responses always include an almost plastic branch. This better performance can be attributed to the fact that in beam pull-out tests, at the loaded-end vicinity, the FRP strip is simultaneously submitted to axial forces and a curvature due to the rotation of the beam. Similar behaviour has been observed in concrete specimens strengthened with the same materials and technique. During the bending test, the relative vertical displacement between the top surface of the groove and the top surface of the bar introduces a lateral confinement pressure in the laminate. Assuming that the behaviour of the CFRP-glulam interface 
Sena-Cruz, J.M.; Jorge, M.; Branco, J.; Cunha, V.M.C.F. (2012) "Bond between glulam and NSM CFRP laminates." Construction \& Building Materials, 40, 260-269.

system can be governed by a Mohr-Coulomb model, this lateral pressure increases the bond resistance, which is responsible for the higher peak bond force registered in the BPT. This behaviour also contributes for the superior stiffness observed in the beam pull-out tests. This effect can be easily observed by the distinct slope of the linear branches of the curves $F_{1}-S_{1}$ (see Fig. 3). For both BPT and DPT tests the maximum pull-out force is attained when the bond length is equal to $120 \mathrm{~mm}$.

Analyzing the results included in Tables 1 and 2 the following main conclusions can be pointed out:

- As expected, the $F_{\text {fmax }}$ increased with the bond length up to $L_{\mathrm{b}}=120 \mathrm{~mm}$. For higher bond lengths, the $F_{\text {fmax }}$ remains practically constant;

- Similarly to the $F_{\text {fmax }}$, the pull-out efficiency, defined by the $F_{\text {fmax }} / F_{\text {fu }}$ ratio, increased also with the bond length up to $L_{b}=120 \mathrm{~mm}$. For the case of the BPT, an average ratio of about $45 \%$ was attained in the series BPT_Lb180;

- As expected, bond strength has decreased with the increase of the bond length (see columns of $\tau_{\max , \mathrm{av} 1}$ and $\left.\tau_{\max , \mathrm{av} 2}\right)$ due to the non-constant tangential stress along the longitudinal axis of the CFRP, as referred in the literature [14]. It was also expectable higher values for $\tau_{\text {max,av1 }}$ when compared with $\tau_{\text {max,av2 }}$, since the contact area for the latter is larger;

- In general, all the parameters presented quite low values of the corresponding coefficients of variation. The exception is for the values of slips at the loaded and free-ends. In fact high coefficients of variation were observed, and an eventual justification can be attributed to the difficulty in measuring this physical entity.

The principal observed failure modes were (see Fig. 4): (i) glulam shear failure (GS); (ii) glulam/adhesive interfacial sliding (GAI); (iii) FRP/adhesive interfacial sliding (FAI); (iv) adhesive splitting (SPL); and, (v) adhesive cracking (CR). In several cases a combination of the above mentioned failure modes was observed. It is clear that in the case of DPT series the FRP/adhesive interfacial sliding with adhesive cracking is the typical failure mode (with the exception of DPT_Lb30 series). Moreover, in some specimens due to the adhesive splitting it is possible to see the resistant mechanism reported in the literature [15] for the NSM technique. Diagonal compressive forces (struts) are developed in the adhesive and then are transferred to glulam. This behaviour is clearly observed in Fig. 4 (GS+FAI+CR) where the "fish spine" crack pattern is observed on the epoxy adhesive. In the case of the BPT series a mix of 
Sena-Cruz, J.M.; Jorge, M.; Branco, J.; Cunha, V.M.C.F. (2012) "Bond between glulam and NSM CFRP laminates." Construction \& Building Materials, 40, 260-269.

glulam/adhesive and FRP/adhesive interfacial sliding characterize the typical observed failure mode. The stress state promoted by this test configuration, which yields to the CFRP sliding and rotation, may explain this behaviour.

Fig. 5 presents the influence of the bond length $\left(L_{b}\right)$ on the following parameters: pull-out force efficiency $\left(F_{\max } / F_{\text {fu }}\right)$, loaded-end slip $\left(s_{\mathrm{l}}\right)$, average bond strength at FRP/adhesive interface $\left(\tau_{\text {av1 }}\right)$, and average bond strength at adhesive/glulam interface $\left(\tau_{\mathrm{av} 2}\right)$. The $F_{\max } / F_{\text {fu }}$ ratio and the $s_{1}$ have increased with the bond length up to $L_{b}=120 \mathrm{~mm}$, keeping almost constant after this length value. As referred before, generally higher performance was observed for the case of BPT. Up to $120 \mathrm{~mm}$ of bond length, the DPT presents higher deformations, when compared with BPT. This behaviour is changed for $L_{\mathrm{b}}=180 \mathrm{~mm}$. The decrease of the average bond stress with the increment of the bond length in all tested series seems to tend to an asymptotic value.

In spite of the present results being credible and contributing for the knowledge in this area, due to the small number of tests performed (specially the BPT series) further investigation should be done to confirm observed tendencies.

\section{NUMERICAL ANALYSIS}

The mathematical representation of the pull-out phenomenon is generally expressed by a second order differential equation (Naaman et al. 1990 [16], Sujvorakul et al. 2000 [17], Banholzer et al. 2005 [18], Russo et al. 1990 [19], Focacci et al. 2000 [20], Sena-Cruz and Barros 2004 [14]). In the present work the local bond law was established in terms of slip and obtained by an inverse analysis procedure. The detailed description of the analytical model, as well as the inverse analysis strategy can be found elsewhere (Sena-Cruz and Barros 2004 [14], Sena-Cruz et al. 2006 [21]). The adopted analytical model to obtain the local bond stress-slip law has shown a good predictive performance on modelling a diversity of pull-out test results, such as: near-surface mounted CFRP laminate strips (Sena-Cruz et al. 2006 [21]), galvanized steel rebar (Sena-Cruz et al. 2009 [22]), discrete steel fibres embedded in concrete medium (Cunha et al. 2008 [23], 2010 [24]). 
Sena-Cruz, J.M.; Jorge, M.; Branco, J.; Cunha, V.M.C.F. (2012) "Bond between glulam and NSM CFRP laminates.” Construction \& Building Materials, 40, 260-269.

\subsection{Local bond-slip}

Assuming that the CFRP has a linear elastic constitutive law in the longitudinal direction and neglecting the glulam deformability in the slip determination, the second order differential equation that governs the local bond phenomena of the laminate-glulam interface is given by:

$$
\frac{d^{2} s}{d x^{2}}=\frac{P_{f}}{E_{f} A_{f}} \cdot \tau(x)
$$

where $\tau(x)=\tau[s(x)]$ is the local bond shear stress acting on the contact surface between the laminate and the glulam, and $s$ is the slip, i.e. the relative displacement between the CFRP and the glulam. Finally, $\sigma_{f}$, $A_{f}$ and $P_{f}$ are the normal stress, cross section area and perimeter of the CFRP laminate, respectively.

\subsection{Pull-out load-slip relationship}

Consider a CFRP inserted in glulam over a bond length $L_{b}$, where $N$ is the generic applied pull-out force, and $s_{f}$ and $s_{l}$ are, respectively, the free and loaded-end slips (see Fig. 6). When the CFRP is slipping due to an applied pull-out force, $\bar{N}$, the following functions can be evaluated along the laminate bond length: slip along the strip, $s(x)$; bond shear stress along the embedded length, $\tau(x)$; CFRP strain, $\varepsilon_{f}$; and the axial force, $N(x)$, where the origin of $x$ axis coincides with the free extremity of the bond length. The pull-out force is given by Eq. 2, which was obtained by equating both the internal and external work produced, respectively, by the laminate elastic deformation and the bond stress profile at the CFRP interface (SenaCruz et al. 2009 [22]).

$$
N=\sqrt{2 E_{f} \cdot A_{f} \cdot P_{f} \cdot \int_{s_{f}}^{s\left(x=\tilde{L}_{b}\right)} \tau(s) \cdot d s}
$$

The analytical bond stress-slip relationship used in the present work is defined by Eq. 3 , where $\tau_{\mathrm{m}}$ and $s_{m}$ are, respectively, the bond strength and its corresponding slip. Parameter $\alpha$ defines the shape of the pre-peak branch whereas $\alpha^{\prime}$ determines the shape of the post-peak branch.

$$
\tau(s)=\tau_{m}\left(\frac{s}{s_{m}}\right)^{\alpha}, s \leq s_{m} \wedge \tau(s)=\tau_{m}\left(\frac{s}{s_{m}}\right)^{-\alpha^{\prime}}, s>s_{m}
$$


Sena-Cruz, J.M.; Jorge, M.; Branco, J.; Cunha, V.M.C.F. (2012) "Bond between glulam and NSM CFRP laminates." Construction \& Building Materials, 40, 260-269.

\subsection{Numerical results}

The local bond stress-slip relationship for both the direct and bending series was calibrated from the correspondent average experimental pull-out load-slip curve. In this study was primarily intended to model the pull-out behaviour up to the maximum load. On the inverse analysis (IA) procedure, the search of $\alpha$ and $\alpha^{\prime}$ of the local bond relationship was conducted within the interval ]0, 1], whereas for $\tau_{m}$ and $s_{m}$ no boundaries were fixed. For the longitudinal elasticity modulus, the average values obtained on the mechanical characterization of the CFRP laminates were used (see also Section 2.2.2). For the geometrical properties, a cross-sectional area, $A_{f}$, of $28.0 \mathrm{~mm}^{2}$ and a cross-sectional perimeter, $P_{f}$, of 42.8 mm were adopted.

The pull-out force $v s$. loaded-end slip $\left(F_{l}-S_{l}\right)$ curves, obtained by the numerical inverse analysis procedure and experimental tests, are compared in Fig. 7. It is possible to conclude that the implemented numerical strategy can predict with good accuracy the $\left(F_{l}-S_{l}\right)$ curves. Tables 4 and 5 comprise the parameters of the local bond law defined in Eq. 3, which lead to the numerical $\left(F_{l}-s_{l}\right)$ curves for the direct and bending pull-out tests, respectively. The local bond laws obtained by IA from the direct and beam pull-out tests are depicted in Fig. 8a and 8b, respectively. In general, the shape of the distinct local bond laws was quite similar, however a clear scale effect is observed on the laws correspondent to distinct embedded lengths. Tables 4 and 5, also include the normalized error, Err, of the numerical fitting procedure, defined as the difference between the numerical and experimental curves' area divided by the area underneath the experimental curve; the ratio between the maximum experimental pull-out load and the maximum numerical pull-out, $F_{\text {fmax }} / F_{\text {fnum }}$; and the ratio between the loaded-end slip at $F_{\text {fmax }}$ and the loaded-end slip at $F_{\text {fnum }}, s_{\text {fmax }} / s_{\text {fnum. }}$. In general, the obtained Err was relatively small with the exception of BPT_Lb30 and BPT_Lb180 series that exceeded $5 \%$ (see Tables 4 and 5). The $F_{\text {fmax }} / F_{\text {fnum }}$ ratio obtained is close to the unit, [0.973-1.087], except for series BPT_Lb180 with a lower ratio of 0.876 . Nevertheless, this shows the good accuracy on the estimation of the maximum pull-out load. On the other hand, the $s_{\text {fmax }} / s_{\text {fnum }}$ ratio ranged from 0.902 to 1.172

Analyzing the parameters of the local bond stress law obtained by inverse analysis, and included in Tables 4 and 5, the following main conclusions can be pointed out:

- It is not observed a clear trend for the bond length influence on the slip at maximum bond stress, $s_{\mathrm{m}}$, for both the direct and beam pull-out tests; 
Sena-Cruz, J.M.; Jorge, M.; Branco, J.; Cunha, V.M.C.F. (2012) "Bond between glulam and NSM CFRP laminates." Construction \& Building Materials, 40, 260-269.

- The maximum bond stress, $\tau_{\mathrm{m}}$, decreases with the increase of the bond length, for both the direct and beam pull-out series. The $\tau_{\mathrm{m}}$ obtained for the DPT and BPT series with the highest bond length $(180 \mathrm{~mm})$ is, respectively, $57.5 \%$ and $57.1 \%$ lower than for the smallest embedded length $(30 \mathrm{~mm})$. Moreover, higher values of $\tau_{\mathrm{m}}$ were obtained for the BPT configuration. In average terms, $\tau_{\mathrm{m}}$ obtained from beam pull-out tests was nearby 1.13 $(\mathrm{CoV}=5.3 \%)$ times higher than the one obtained from the direct pull-out tests.

- For $\alpha$ parameter, which defines the shape of the pre-peak branch, it was not visualized any clear trend with the embedded length. Nevertheless, the values of $\alpha$ obtained from the simulation of direct pull-out tests where relatively higher than the ones obtained from the bending pull-out tests. An average value of 0.86 was obtained for the direct tests, whereas for the beam tests an average value of 0.66 was obtained. Notice that the allowed interval for parameter $\alpha$ ranges from 0 to 1.0. Moreover, as $\alpha$ tends to 1.0 , the concavity of the pre-peak branch diminishes tending to a straight segment;

- No clear trend was observed for $\alpha^{\prime}$. This was expected since $\alpha^{\prime}$ controls the shape of the postpeak branch bond law, which has more preponderance on the softening phase of the pull-out load - slip response. However, notice that $\alpha$ also influences the pull-out load-slip response up to the maximum load. In Fig. 9 is depicted the local bond stress $\tau$ variation over the CFRP longitudinal embedded length $(x)$ corresponding to the maximum pull-out load. It can be observed, for the maximum pull-out load, that at the loaded-end ( $x=30,60,120$ or $180 \mathrm{~mm})$ the local bond strength, $\tau_{\mathrm{m}}$, was already attained for a lower pull-out force.

Fig. 10 shows the bond length influence on the numerical average bond strength, $\tau_{\mathrm{av}, \text { num }}$, and on the numerical bond strength, $\tau_{\mathrm{m}}$. The values of $\tau_{\mathrm{av}, \text { num }}$, which are included in Tables 4 and 5, were computed in a distinct fashion from the average bond strength $\tau_{\max , a v 1}$ and $\tau_{\max , a v 2}$ obtained from the experimental results. The procedure to calculate $\tau_{\mathrm{av}, \text { num }}$ was the following: $i$ ) for each series, at the maximum pull-out load was obtained the corresponding slip variation over the longitudinal embedded length, $s(x)$; ii) the bond stress variation along the embedded length, $\tau(x)=\tau[\mathrm{s}(x)]$, is determined adopting for the local bond law the parameters obtained from the inverse analysis; iii) the area under $\tau(x)$ is computed; iv) finally $\tau_{\mathrm{av}, \text { num }}$ is obtained by dividing the area under $\tau(x)$ diagram by the corresponding embedment 
Sena-Cruz, J.M.; Jorge, M.; Branco, J.; Cunha, V.M.C.F. (2012) "Bond between glulam and NSM CFRP laminates." Construction \& Building Materials, 40, 260-269.

length, $L_{b}$. In Fig. 9 are depicted $\tau(x), s(x)$ and $\tau_{\text {av,num }}$ obtained for both the direct and beam pull-out series with an embedded length of $60 \mathrm{~mm}$.

The computed values of $\tau_{\mathrm{av}, \text { num }}$, as expected, were smaller than the $\tau_{\mathrm{m}}$. Moreover, in general, they were within or near the envelope of the average bond strength values at the CFRP/adhesive interface, $\tau_{\text {max,av1 }}$, see Fig. 10.

\section{CONCLUSIONS}

This work presented an experimental study on bond characterization between CFRP laminates strips and glulam, using the near surface mounted (NSM) strengthening technique, through direct (DPT) and beam (BPT) pull-out tests. The bond length $\left(L_{b}=30,60,120\right.$ and $\left.180 \mathrm{~mm}\right)$ and the test configuration type (DPT and BPT) were the main variables studied.

The pull-out force $\left(F_{\operatorname{lmax}}\right)$, as well as the ratio between maximum pull-out force and the FRP strength $\left(F_{\operatorname{lmax}} / F_{\mathrm{fu}}\right)$ have increased with $L_{\mathrm{b}}$, up to $L_{\mathrm{b}}=120 \mathrm{~mm}$, keeping almost constant for a bond length of $180 \mathrm{~mm}$.

The loaded and free-ends slips $\left(s_{\mathrm{l}}\right.$ and $\left.s_{\mathrm{f}}\right)$ have increased with the increment of $L_{\mathrm{b}}$.

In general, higher values of $F_{\operatorname{lmax}}, \tau_{\mathrm{av} 1}$ and $\tau_{\mathrm{av} 2}$ were obtained in the BPT series, whereas superior values of $s_{1}$ were registered on the DPT series. The better performance obtained with the beam pull-out test configuration can be explained by the favourable fact of the specimens being submitted to a flexural action yielding a superior resistance at the FRP/adhesive/glulam level.

The maximum $F_{\operatorname{lmax}} / F_{\text {fu }}$ ratio attained was about $45 \%$ for the BPT series.

Failure modes included glulam shear failure, interfacial failure glulam/adhesive, interfacial failure FRP/adhesive, adhesive cracking and adhesive splitting.

Using a numerical approach, a local bond stress-slip relationship was obtained from the test results. The maximum bond stress used to define the local bond law was, however, found to be significantly dependent on the bond length.

\section{ACKNOWLEDGEMENTS}

This work is supported by FEDER funds through the Operational Programme for Competitiveness Factors - COMPETE and National Funds through FCT - Portuguese Foundation for Science and 
Sena-Cruz, J.M.; Jorge, M.; Branco, J.; Cunha, V.M.C.F. (2012) "Bond between glulam and NSM CFRP laminates." Construction \& Building Materials, 40, 260-269.

Technology under the project PTDC/ECM/74337/2006. The authors also like to thank all the companies that have been involved supporting and contributing for the development of this study, mainly: S\&P Clever Reinforcement Ibérica Lda., Portilame, MAPEI and Rothoblaas. 
Sena-Cruz, J.M.; Jorge, M.; Branco, J.; Cunha, V.M.C.F. (2012) "Bond between glulam and NSM CFRP laminates." Construction \& Building Materials, 40, 260-269.

\section{REFERENCES}

1. ACI 440.2R-08. Guide for the Design and Construction of Externally Bonded FRP Systems for Strengthening Concrete Structures. Reported by ACI Committee 440, American Concrete Institute, 2008, 80 pp.

2. De Lorenzis L., Teng J.G. Near-surface mounted FRP reinforcement: An emerging technique for strengthening structures. Composites Part B 2007, 38(2):119-143.

3. Borri A, Corradi M, Grazini A. A method for flexural reinforcement of old wood beams with CFRP materials. Composites: Part B 2005, 36, 143-153.

4. Johnsson H, Blanksvärd T, Carolin A. Glulam members strengthened by carbon fibre reinforcement. Materials and Structures 2006, 40, 47-56.

5. Ahmad Y. Bending behavior of timber beams strengthened using fiber reinforced polymer bars and plates. PhD Dissertation, Faculty of Civil Engineering, Technology University of Malaysia, 2010, $306 \mathrm{pp}$.

6. NP EN 1194:1999. Timber structures. Glulam wood. Strength classes and determination of the characteristic values. Instituto Português da Qualidade, Lisbon, 2009. (in Portuguese)

7. EN 408. Timber structures - Structural timber and glued laminated timber. Determination of some physical and mechanical properties. European Committee for Standardization (CEN), 2003, 31 pp.

8. ISO 3130. Wood - Determination of moisture content for physical and mechanical tests. International Organization for Standardization (ISO), 1975.

9. ISO 3131. Wood - Determination of density for physical and mechanical tests” International Organization for Standardization (ISO), 1975.

10. ISO 527-5. Plastics - Determination of tensile properties - Part 5: Test conditions for unidirectional fibre-reinforced plastic composites. International Organization for Standardization (ISO), 1997.

11. ISO 527-2. Plastics - Determination of tensile properties - Part 2: Test conditions for molding and extrusion plastics. International Organization for Standardization (ISO), 1993.

12. Barros JAO, Dias SJE, Lima JLT. Efficacy of CFRP-based techniques for the flexural and shear strengthening of concrete beams. Cement and Concrete Composites 2007, 29(3):203-217.

13. Jorge MAP. Experimental behavior of glulam-FRP systems. MSc thesis, Department of Civil Engineering, University of Minho, 2010, 247 pp. 
Sena-Cruz, J.M.; Jorge, M.; Branco, J.; Cunha, V.M.C.F. (2012) "Bond between glulam and NSM CFRP laminates." Construction \& Building Materials, 40, 260-269.

14. Sena-Cruz JM, Barros JAO. Modeling of bond between near-surface mounted CFRP laminate strips and concrete. Computers and Structures Journal 2004, 82:1513-1521.

15. Sena-Cruz JM, Barros JAO. Bond Between Near-Surface Mounted Carbon-Fiber-Reinforced Polymer Laminate Strips and Concrete. Journal of Composites for Construction 2004, 8(6):519-527.

16. Naaman AE, Namur GG, Alwan JM, Najm HS. Fiber pull-out and bond slip I: Analytical study. Structural Engineering 1990, 117(9):2769-2790.

17. Sujivorakul C, Waas AM, Naaman A. Pull-out response of a smooth fiber with an end anchorage. Engineering Mechanics 2000, 126(9):986-993.

18. Banholzer B, Brameshuber W, Jung W. Analytical simulation of pull-out tests - the direct problem. Cement \& Concrete Composites 2005, 27:93-101.

19. Russo G, Zingone G, Romano F. Analytical solution for bond-slip of reinforcing bars in R.C. joints. Structural Engineering 1990, 116(2):336-355.

20. Focacci F, Nanni A, Bakis C. Local bond-slip relationship for FRP reinforcement in concrete. Composites for Construction 2000, 4(1):24-31.

21. Sena-Cruz JM, Barros JAO, Gettu R, Azevedo AFM. Bond behavior of near-surface mounted CFRP laminate strips under monotonic and cyclic loading. Composites for Construction 2006, 10(4):295303.

22. Sena-Cruz JM, Cunha VMCF, Camões A, Barros JAO, Cruz P. Modeling of bond between galvanized steel rebars and concrete. In: Proceedings of Congreso de Métodos Numéricos en Ingeniería, CIMNE, Barcelona, Spain, 2009, 15 pp.

23. Cunha, V.M.C.F., Barros J.A.O., Sena-Cruz J.M. Bond-slip mechanisms of hooked-end steel fibres in self-compacting concrete. Materials Science Forum 2008, 587-588:877-881.

24. Cunha, V.M.C.F., Sena-Cruz, J.M., Barros, J. A. O. Pullout Behavior of Steel Fibers in SelfCompacting Concrete. ASCE Journal Materials in Civil Engineering 2008, 22(1):1-9. 
Sena-Cruz, J.M.; Jorge, M.; Branco, J.; Cunha, V.M.C.F. (2012) "Bond between glulam and NSM CFRP laminates.” Construction \& Building Materials, 40, 260-269.

\section{TABLE CAPTIONS}

Table 1 - Main results obtained on the direct pull-out tests, DPT (average values)

Table 2 - Main results obtained on the beam pull-out tests, BPT (average values)

Table 3 - Local bond stress-slip relationship parameters obtained from IA of the DPT

Table 4 - Local bond stress-slip relationship parameters obtained from IA of the BPT 
Sena-Cruz, J.M.; Jorge, M.; Branco, J.; Cunha, V.M.C.F. (2012) "Bond between glulam and NSM CFRP laminates.” Construction \& Building Materials, 40, 260-269.

Table 1 - Main results obtained on the direct pull-out tests, DPT (average values)

\begin{tabular}{|c|c|c|c|c|c|c|c|}
\hline Specimen & $\begin{array}{l}\boldsymbol{F}_{\text {fmax }} \\
{[\mathrm{kN}]}\end{array}$ & $\begin{array}{c}\boldsymbol{F}_{\mathrm{fmax}} / \boldsymbol{F}_{\mathrm{fu}} \\
{[\%]}\end{array}$ & $\begin{array}{l}\tau_{\text {max,av1 }} \\
{[\mathrm{MPa}]}\end{array}$ & $\begin{array}{l}\tau_{\text {max,av2 }} \\
{[\mathrm{MPa}]}\end{array}$ & $\begin{array}{l}s_{\mathrm{fmax}} \\
{[\mathrm{mm}]}\end{array}$ & $\begin{array}{c}S_{\operatorname{lmax}} \\
{[\mathrm{mm}]}\end{array}$ & $\begin{array}{c}\text { Failure } \\
\text { mode }\end{array}$ \\
\hline DPT_Lb30_1 & 16.64 & 20.82 & 12.96 & 9.71 & 0.239 & 0.331 & GAI \\
\hline DPT_Lb30_2 & 14.05 & 17.58 & 10.94 & 8.20 & 0.179 & 0.208 & GAI \\
\hline DPT_Lb30_3 & 16.50 & 20.64 & 12.85 & 9.55 & 0.253 & 0.310 & GAI \\
\hline DPT_Lb30_4 & 16.46 & 20.60 & 12.82 & 9.53 & 0.211 & 0.384 & $\mathrm{GAI}+\mathrm{CR}$ \\
\hline DPT_Lb30_5 & 17.12 & 21.42 & 13.33 & 9.96 & 0.287 & 0.430 & FAI \\
\hline DPT_Lb30_6 & 15.55 & 19.04 & 11.85 & 8.83 & 0.175 & 0.356 & GAI \\
\hline DPT_Lb30_7 & 15.28 & 19.11 & 11.90 & 8.99 & 0.212 & 0.289 & GAI \\
\hline DPT_Lb30 & $\begin{array}{c}15.90 \\
(6.8 \%)\end{array}$ & $\begin{array}{c}19.89 \\
(6.8 \%)\end{array}$ & $\begin{array}{c}12.38 \\
(6.8 \%)\end{array}$ & $\begin{array}{c}9.25 \\
(6.6 \%)\end{array}$ & $\begin{array}{c}0.22 \\
(18.1 \%)\end{array}$ & $\begin{array}{c}0.33 \\
(21.3 \%)\end{array}$ & - \\
\hline DPT_Lb60_1 & 23.77 & 29.73 & 9.25 & 6.99 & 0.278 & 0.463 & $\mathrm{FAI}+\mathrm{CR}$ \\
\hline DPT_Lb60_2 & 24.58 & 30.75 & 9.57 & 7.10 & 0.254 & 0.455 & $\mathrm{FAI}+\mathrm{CR}$ \\
\hline DPT_Lb60_3 & 24.33 & 30.44 & 9.47 & 7.11 & 0.410 & 0.639 & $\mathrm{FAI}+\mathrm{CR}$ \\
\hline DPT_Lb60_4 & 18.34 & 22.95 & 7.14 & 5.36 & 0.357 & 0.523 & $\mathrm{FAI}+\mathrm{CR}$ \\
\hline DPT_Lb60_5 & 21.21 & 26.53 & 8.26 & 6.23 & 0.216 & 0.406 & GAI \\
\hline DPT_Lb60_6 & 22.35 & 27.96 & 8.70 & 6.53 & 0.283 & 0.432 & GAI \\
\hline DPT_Lb60_7 & 22.89 & 28.63 & 8.91 & 6.69 & 0.262 & 0.401 & $\mathrm{FAI}+\mathrm{CR}$ \\
\hline DPT_Lb60 & $\begin{array}{c}22.49 \\
(9.7 \%) \\
\end{array}$ & $\begin{array}{c}28.14 \\
(9.7 \%) \\
\end{array}$ & $\begin{array}{c}8.76 \\
(9.7 \%) \\
\end{array}$ & $\begin{array}{c}6.57 \\
(9.5 \%) \\
\end{array}$ & $\begin{array}{c}0.29 \\
(22.6 \%) \\
\end{array}$ & $\begin{array}{c}0.47 \\
(17.6 \%) \\
\end{array}$ & - \\
\hline DPT_Lb120_1 & 30.30 & 37.90 & 5.90 & 4.44 & 0.949 & 1.136 & $\mathrm{FAI}+\mathrm{SPL}$ \\
\hline DPT_Lb120_2 & 27.18 & 34.00 & 5.29 & 3.95 & 0.448 & 0.889 & $\mathrm{GAI}+\mathrm{SPL}+\mathrm{CR}$ \\
\hline DPT_Lb120_3 & 30.95 & 38.72 & 6.03 & 4.52 & 0.304 & 0.797 & $\mathrm{FAI}+\mathrm{CR}$ \\
\hline DPT_Lb120_4 & 36.62 & 45.81 & 7.13 & 5.34 & 0.333 & 0.894 & $\mathrm{FAI}+\mathrm{CR}$ \\
\hline DPT_Lb120_5 & 31.09 & 38.90 & 6.05 & 4.54 & 0.250 & 0.671 & $\mathrm{FAI}+\mathrm{CR}$ \\
\hline DPT_Lb120_6 & 26.61 & 33.29 & 5.18 & 3.91 & 0.273 & 0.675 & $\mathrm{FAI}+\mathrm{CR}$ \\
\hline DPT_Lb120_7 & 25.43 & 31.82 & 4.95 & 3.73 & 0.171 & 0.581 & $\mathrm{GAI}+\mathrm{FAI}$ \\
\hline DPT_Lb120 & $\begin{array}{c}29.74 \\
(12.7 \%) \\
\end{array}$ & $\begin{array}{c}37.21 \\
(12.7 \%)\end{array}$ & $\begin{array}{c}5.79 \\
(12.7 \%)\end{array}$ & $\begin{array}{c}4.35 \\
(12.5 \%)\end{array}$ & $\begin{array}{c}0.39 \\
(67.0 \%) \\
\end{array}$ & $\begin{array}{c}0.81 \\
(23.2 \%) \\
\end{array}$ & - \\
\hline DPT_Lb180_1 & 29.79 & 37.27 & 3.87 & 2.91 & 0.302 & 0.681 & $\mathrm{FAI}+\mathrm{CR}$ \\
\hline DPT_Lb180_2 & 26.04 & 32.58 & 3.38 & 2.55 & 0.192 & 0.776 & $\mathrm{FAI}+\mathrm{CR}$ \\
\hline DPT_Lb180_3 & 27.17 & 33.99 & 3.53 & 2.61 & 0.516 & 0.862 & $\mathrm{FAI}+\mathrm{CR}$ \\
\hline DPT_Lb180_4 & 30.43 & 38.07 & 3.95 & 2.95 & 0.327 & 0.897 & $\mathrm{FAI}+\mathrm{CR}$ \\
\hline DPT_Lb180_5 & 30.09 & 37.64 & 3.91 & 2.93 & 0.296 & 0.562 & $\mathrm{FAI}+\mathrm{CR}$ \\
\hline DPT_Lb180_6 & 28.08 & 35.15 & 3.65 & 2.74 & 0.518 & 0.915 & $\mathrm{FAI}+\mathrm{CR}$ \\
\hline DPT_Lb180_7 & 26.52 & 33.18 & 3.44 & 2.59 & 0.123 & 0.737 & $\mathrm{FAI}+\mathrm{CR}$ \\
\hline DPT_Lb180 & $\begin{array}{c}28.31 \\
(6.4 \%)\end{array}$ & $\begin{array}{c}35.41 \\
(6.4 \%)\end{array}$ & $\begin{array}{c}3.67 \\
(6.4 \%)\end{array}$ & $\begin{array}{c}2.75 \\
(6.3 \%)\end{array}$ & $\begin{array}{c}0.32 \\
(46.0 \%)\end{array}$ & $\begin{array}{c}0.78 \\
(16.4 \%)\end{array}$ & - \\
\hline
\end{tabular}

Notes: FAI - interfacial failure FRP/adhesive; GAI - interfacial failure glulam/adhesive; SPL - adhesive splitting; GS - glulam shear failure; CR - adhesive cracking; FF - FRP failure; the values between parentheses are the corresponding coefficients of variation. 
Sena-Cruz, J.M.; Jorge, M.; Branco, J.; Cunha, V.M.C.F. (2012) "Bond between glulam and NSM CFRP laminates." Construction \& Building Materials, 40, 260-269.

Table 2 - Main results obtained on the beam pull-out tests, BPT (average values)

\begin{tabular}{|c|c|c|c|c|c|c|c|}
\hline Specimen & $\begin{array}{c}\boldsymbol{F}_{\text {fmax }} \\
{[\mathrm{kN}]}\end{array}$ & $\begin{array}{c}\boldsymbol{F}_{\mathrm{fmax}} / \boldsymbol{F}_{\mathrm{fu}} \\
{[\%]}\end{array}$ & $\begin{array}{c}\tau_{\text {max,av1 }} \\
{[\mathrm{MPa}]}\end{array}$ & $\begin{array}{l}\tau_{\text {max,av2 }} \\
{[\mathrm{MPa}]}\end{array}$ & $\begin{array}{c}\boldsymbol{s}_{\mathrm{fmax}} \\
{[\mathrm{mm}]}\end{array}$ & $\begin{array}{c}\boldsymbol{S}_{\operatorname{lmax}} \\
{[\mathrm{mm}]}\end{array}$ & Failure mode \\
\hline BPT_Lb30_1 & 15.70 & 21.1 & 12.08 & 9.06 & 0.259 & 0.232 & $\mathrm{GAI}+\mathrm{FAI}+\mathrm{CR}$ \\
\hline BPT_Lb30_2 & 16.54 & 22.2 & 12.71 & 9.63 & 0.201 & 0.191 & $\mathrm{GAI}+\mathrm{FAI}+\mathrm{CR}$ \\
\hline BPT_Lb30_3 & 16.88 & 22.7 & 12.98 & 9.88 & 0.184 & 0.371 & $\mathrm{GAI}+\mathrm{FAI}+\mathrm{CR}$ \\
\hline BPT_Lb30 & $\begin{array}{c}16.37 \\
(3.7 \%)\end{array}$ & $\begin{array}{c}22.00 \\
(3.7 \%)\end{array}$ & $\begin{array}{c}12.59 \\
(3.7 \%)\end{array}$ & $\begin{array}{c}9.52 \\
(4.4 \%)\end{array}$ & $\begin{array}{c}0.215 \\
(18.3 \%)\end{array}$ & $\begin{array}{c}0.265 \\
(35.6 \%)\end{array}$ & - \\
\hline BPT_Lb60_1 & 26.13 & 35.1 & 10.05 & 7.61 & 0.155 & 0.347 & GS \\
\hline BPT_Lb60_2 & 25.19 & 33.8 & 9.69 & 7.35 & 0.183 & 0.321 & $\mathrm{GAI}+\mathrm{CR}$ \\
\hline BPT_Lb60_3 & 26.14 & 35.1 & 10.05 & 7.65 & 0.430 & 0.416 & $\mathrm{GAI}+\mathrm{FAI}+\mathrm{CR}$ \\
\hline BPT_Lb60 & $\begin{array}{c}25.82 \\
(2.1 \%)\end{array}$ & $\begin{array}{c}34.67 \\
(2.2 \%)\end{array}$ & $\begin{array}{c}9.93 \\
(2.1 \%)\end{array}$ & $\begin{array}{c}7.54 \\
(2.2 \%)\end{array}$ & $\begin{array}{c}0.256 \\
(59.1 \%)\end{array}$ & $\begin{array}{c}0.361 \\
(13.6 \%)\end{array}$ & - \\
\hline BPT_Lb120_1 & 32.63 & 43.8 & 6.27 & 4.78 & 0.109 & 0.827 & GAI \\
\hline BPT_Lb120_2 & 31.34 & 42.1 & 6.03 & 4.59 & 0.090 & 0.744 & $\mathrm{FAI}+\mathrm{CR}$ \\
\hline BPT_Lb120_3 & 32.58 & 43.7 & 6.26 & 4.79 & 0.086 & 0.770 & $\mathrm{GS}+\mathrm{FAI}+\mathrm{CR}$ \\
\hline BPT_Lb120 & $\begin{array}{c}32.18 \\
(2.3 \%)\end{array}$ & $\begin{array}{c}43.20 \\
(2.2 \%)\end{array}$ & $\begin{array}{c}6.19 \\
(2.2 \%)\end{array}$ & $\begin{array}{c}4.72 \\
(2.4 \%)\end{array}$ & $\begin{array}{c}0.095 \\
(12.9 \%)\end{array}$ & $\begin{array}{c}0.780 \\
(5.4 \%)\end{array}$ & - \\
\hline BPT_Lb180_1 & 33.14 & 44.5 & 4.25 & 3.21 & 0.029 & 1.178 & $\mathrm{FAI}+\mathrm{CR}$ \\
\hline BPT_Lb180_2 & 32.96 & 44.2 & 4.22 & 3.22 & 0.007 & 0.828 & $\mathrm{GS}+\mathrm{FAI}+\mathrm{CR}$ \\
\hline BPT_Lb180_3 & 33.82 & 45.4 & 4.33 & 3.25 & 0.021 & 0.783 & $\mathrm{GAI}+\mathrm{FAI}+\mathrm{CR}$ \\
\hline BPT_Lb180 & $\begin{array}{c}33.31 \\
(1.4 \%)\end{array}$ & $\begin{array}{c}44.70 \\
(1.4 \%)\end{array}$ & $\begin{array}{c}4.27 \\
(1.4 \%)\end{array}$ & $\begin{array}{c}3.23 \\
(0.6 \%)\end{array}$ & $\begin{array}{c}0.019 \\
(58.6 \%)\end{array}$ & $\begin{array}{c}0.930 \\
(23.3 \%)\end{array}$ & - \\
\hline
\end{tabular}

Notes: FAI - interfacial failure FRP/adhesive; GAI - interfacial failure glulam/adhesive; SPL - adhesive splitting; GS - glulam shear failure; CR - adhesive cracking; FF - FRP failure; the values between parentheses are the corresponding coefficients of variation. 
Sena-Cruz, J.M.; Jorge, M.; Branco, J.; Cunha, V.M.C.F. (2012) "Bond between glulam and NSM CFRP laminates.” Construction \& Building Materials, 40, 260-269.

Table 3 - Local bond stress-slip relationship parameters obtained from IA of the DPT

\begin{tabular}{ccccccccc}
\hline \hline Series & $s_{\mathrm{m}}$ & $\tau_{\mathrm{m}}$ & $\alpha$ & $\alpha$ & Err. & $s_{\text {fmax }} / s_{\text {fnum }}$ & $F_{\text {fmax }} / F_{\text {fnum }}$ & $\tau_{\text {av,num }}$ \\
& {$[\mathrm{mm}]$} & {$[\mathrm{MPa}]$} & {$[-]$} & {$[-]$} & {$[\%]$} & {$[-]$} & {$[-]$} & {$[\mathrm{MPa}]$} \\
\hline \hline DPT_Lb30 & 0.28 & 11.65 & 0.90 & 0.11 & 2.1 & 1.187 & 1.087 & 11.57 \\
DPT_Lb60 & 0.30 & 8.15 & 0.90 & 0.14 & 1.7 & 1.034 & 1.031 & 7.99 \\
DPT_Lb120 & 0.40 & 6.10 & 0.85 & 0.14 & 1.0 & 1.062 & 1.019 & 5.87 \\
DPT_Lb180 & 0.32 & 4.95 & 0.80 & 0.90 & 2.1 & 1.102 & 0.989 & 3.65 \\
\hline \hline
\end{tabular}


Sena-Cruz, J.M.; Jorge, M.; Branco, J.; Cunha, V.M.C.F. (2012) "Bond between glulam and NSM CFRP laminates.” Construction \& Building Materials, 40, 260-269.

Table 4 - Local bond stress-slip relationship parameters obtained from IA of the BPT

\begin{tabular}{ccccccccc}
\hline \hline Series & $s_{\mathrm{m}}$ & $\tau_{\mathrm{m}}$ & $\alpha$ & $\alpha$ & Err. & $s_{\text {fmax }} / s_{\text {fnum }}$ & $F_{\text {fmax }} / F_{\text {fnum }}$ & $\tau_{\text {av,num }}$ \\
& {$[\mathrm{mm}]$} & {$[\mathrm{MPa}]$} & {$[-]$} & {$[-]$} & {$[\%]$} & {$[-]$} & {$[-]$} & {$[\mathrm{MPa}]$} \\
\hline \hline BPT_Lb30 & 0.16 & 12.20 & 0.94 & 0.14 & 6.4 & 0.986 & 1.000 & 12.59 \\
BPT_Lb60 & 0.19 & 9.90 & 0.61 & 0.15 & 2.2 & 1.172 & 1.063 & 9.55 \\
BPT_Lb120 & 0.25 & 6.70 & 0.44 & 0.16 & 3.6 & 1.217 & 0.973 & 6.29 \\
BPT_Lb180 & 0.18 & 5.45 & 0.88 & 0.22 & 5.5 & 0.902 & 0.876 & 4.08 \\
\hline \hline
\end{tabular}


Sena-Cruz, J.M.; Jorge, M.; Branco, J.; Cunha, V.M.C.F. (2012) "Bond between glulam and NSM CFRP laminates.” Construction \& Building Materials, 40, 260-269.

\section{FIGURE CAPTIONS}

Fig. 1 - Direct pull-out tests: (a) Specimen geometry and configuration; (b) Layout. Note: all dimensions are in millimetres.

Fig. 2 - Beam pull-out tests: (a) Specimen geometry and configuration; (b) Layout. Note: all dimensions are in millimetres.

Fig. 3 - Pull-out force vs. loaded-end slip for the direct (a) and beam (b) pull-out tests (average curves). Fig. 4 - Typical failure modes observed in the pull-out tests. Note: GAI - Glulam/adhesive interfacial sliding; FAI - FRP/adhesive interfacial sliding; CR - adhesive cracking; SPL - adhesive splitting; GS glulam shear failure.

Fig. 5 - Bond length influence on: (a) efficiency in terms of maximum load; (b) loaded-end slip; (c) average bond strength $\tau_{\mathrm{av} 1} ;$ (d) average bond strength $\tau_{\mathrm{av} 2}$.

Fig. 6 - Entities in the analytical model.

Fig. 7 - Pull-out force vs. loaded-end slip relationships obtained by inverse analysis for the: (a) direct and (b) bending pull-out tests.

Fig. 8 - Variation of the local bond with the embedded length $\left(L_{b}\right)$ for: (a) direct and (b) beam pull-out tests.

Fig. 9 - Bond length influence on the numerical average bond strength $\tau_{\mathrm{av}, \mathrm{num}}$ and numerical bond strength $\tau_{\mathrm{m}}$.

Fig. 10 - Variation of the bond stress, $\tau$, and slip, $s$, along the CFRP longitudinal embedded length $(x)$ at the maximum pull-out load for the series: (a) DPT_Lb60 and (b) BPT_Lb60. 


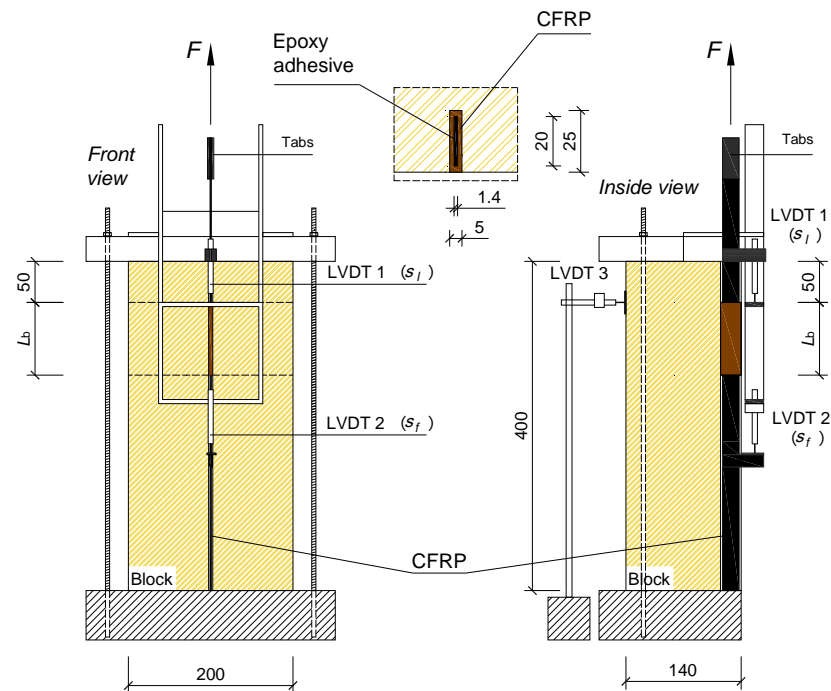

(a)

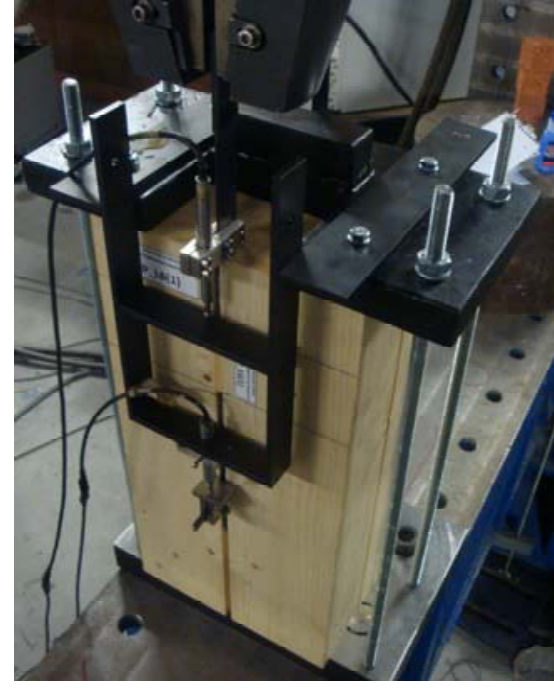

(b)

Fig. 1: Direct pull-out tests: (a) Specimen geometry and configuration; (b) Layout. Note: all dimensions are in millimetres. 
Sena-Cruz, J.M.; Jorge, M.; Branco, J.; Cunha, V.M.C.F. (2012) "Bond between glulam and NSM CFRP laminates." Construction \& Building Materials, 40, 260-269.
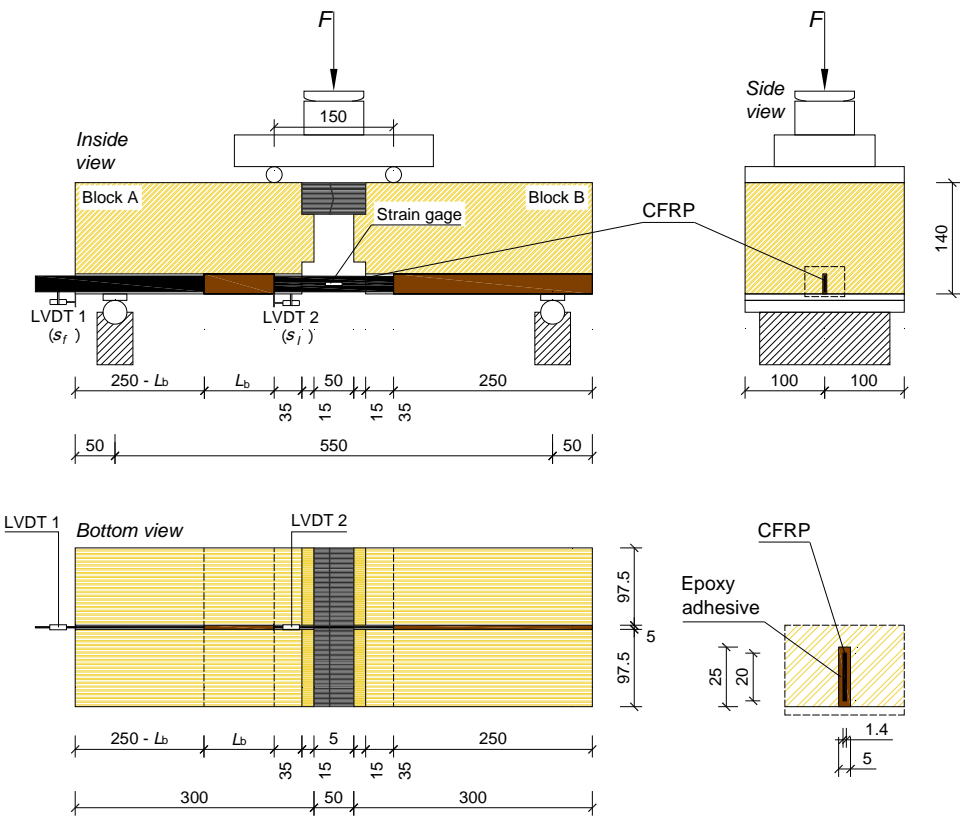

(a)

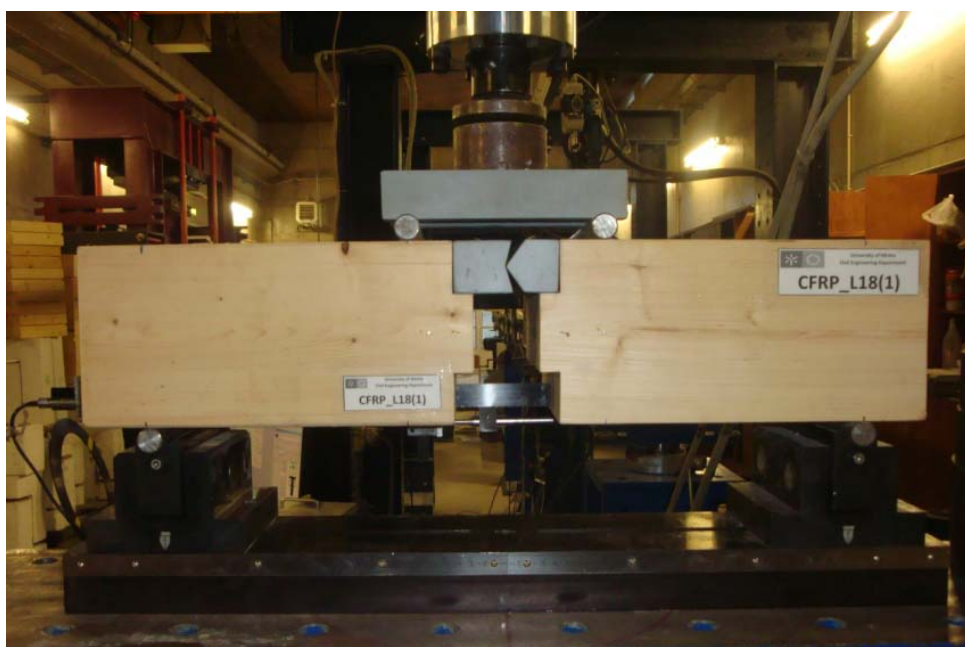

(b)

Fig. 2: Beam pull-out tests: (a) Specimen geometry and configuration; (b) Layout. Note: all dimensions are in millimetres. 
Sena-Cruz, J.M.; Jorge, M.; Branco, J.; Cunha, V.M.C.F. (2012) "Bond between glulam and NSM CFRP laminates." Construction \& Building Materials, 40, 260-269.

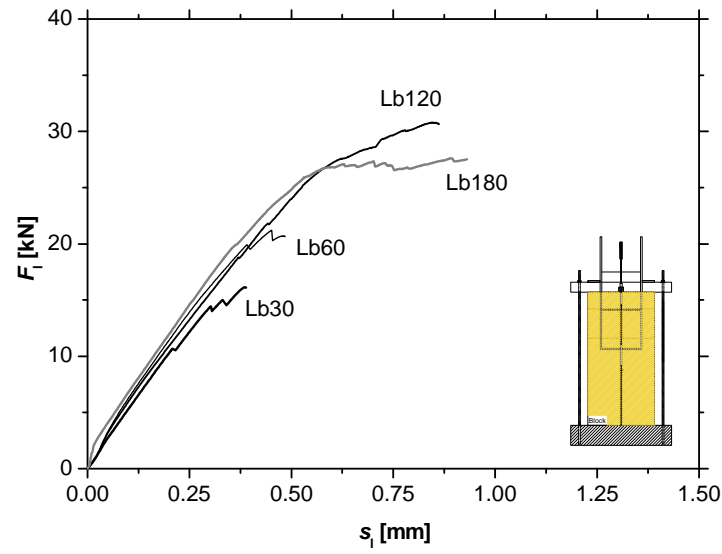

(a)

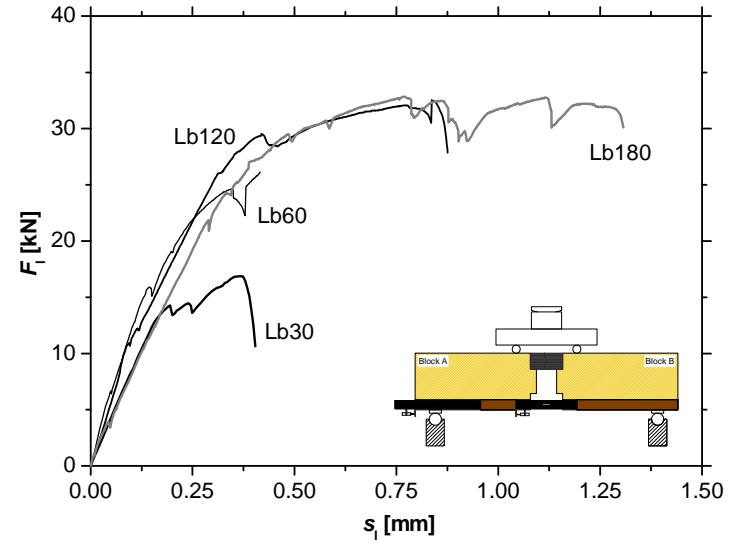

(b)

Fig. 3 - Pull-out force vs. loaded-end slip for the direct (a) and beam (b) pull-out tests (average curves). 


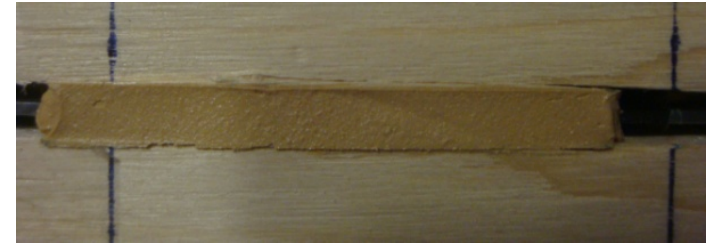

GAI

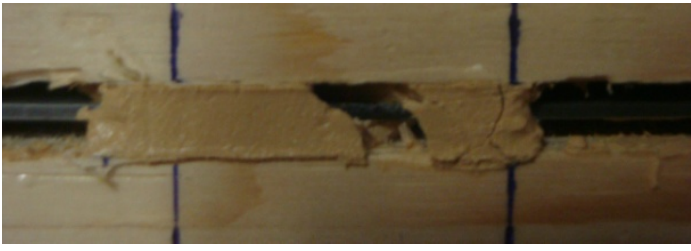

$\mathrm{GAI}+\mathrm{CR}$

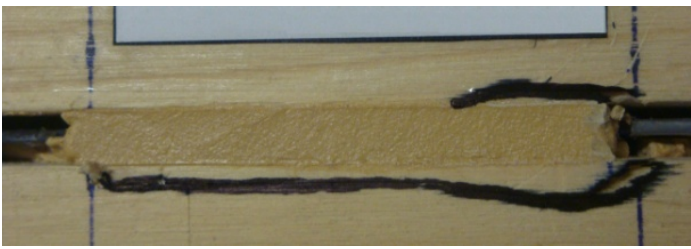

GS

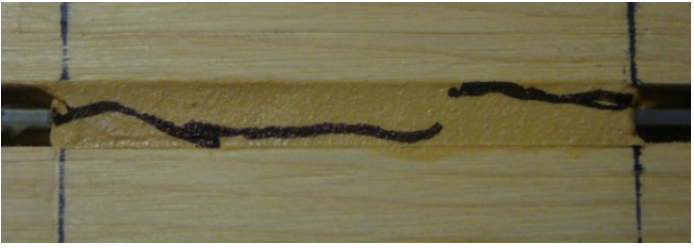

$\mathrm{FAI}+\mathrm{CR}$

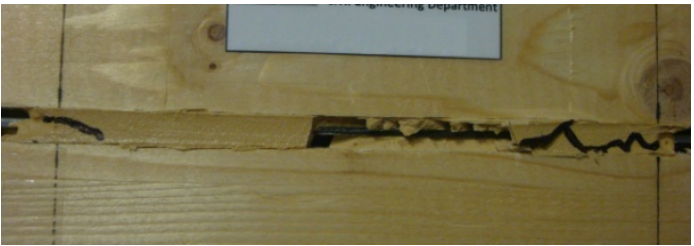

$\mathrm{FAI}+\mathrm{SPL}$

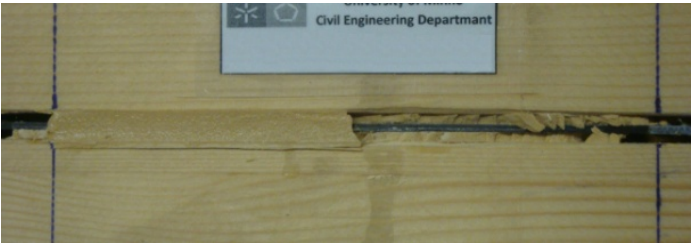

$\mathrm{GS}+\mathrm{FAI}+\mathrm{CR}$

Fig. 4 - Typical failure modes observed in the pull-out tests. Note: GAI - Glulam/adhesive interfacial sliding; FAI - FRP/adhesive interfacial sliding; CR - adhesive cracking; SPL - adhesive splitting; GS glulam shear failure. 
Sena-Cruz, J.M.; Jorge, M.; Branco, J.; Cunha, V.M.C.F. (2012) "Bond between glulam and NSM CFRP laminates." Construction \& Building Materials, 40, 260-269.

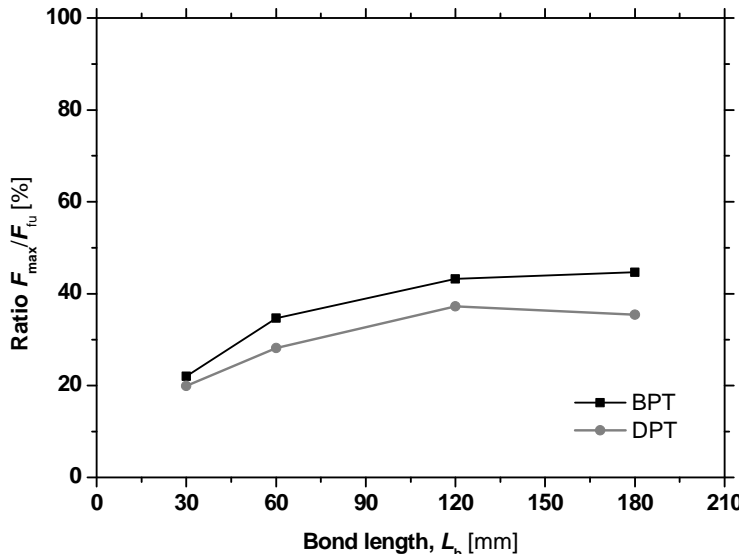

(a)

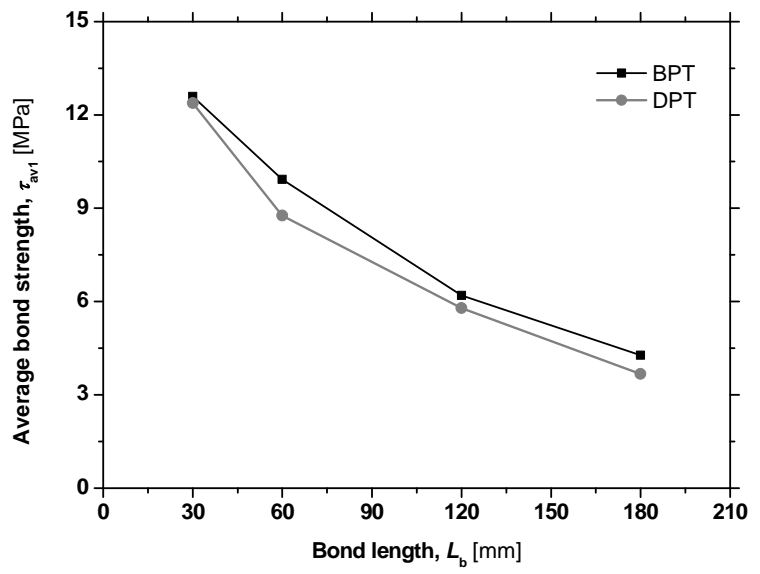

(c)

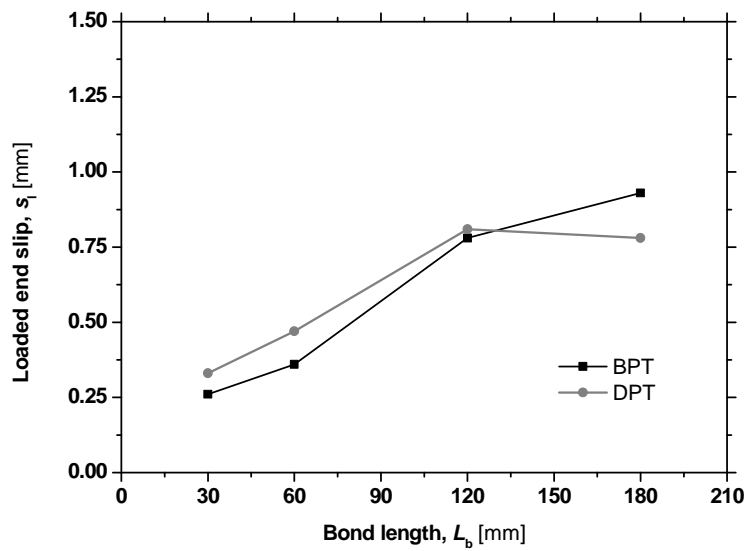

(b)

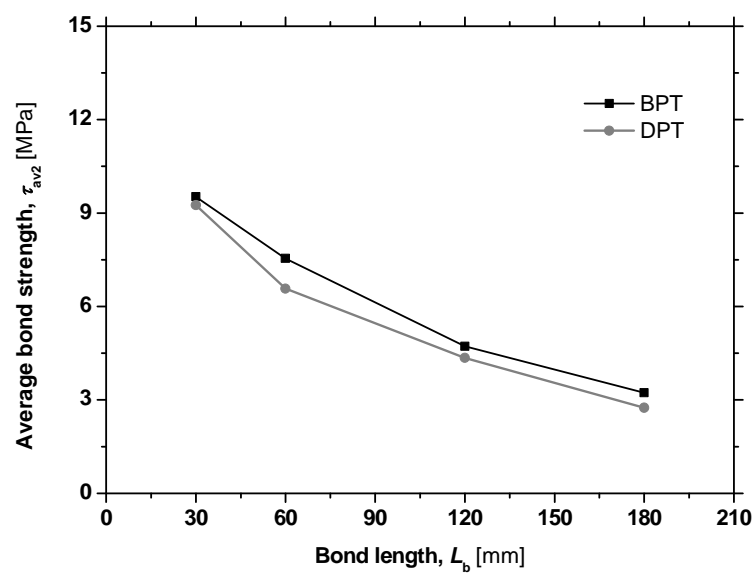

(d)

Fig. 5 - Bond length influence on: (a) efficiency in terms of maximum load; (b) loaded-end slip; (c) average bond strength $\tau_{\text {av1 }}$; (d) average bond strength $\tau_{\mathrm{av} 2}$. 
Sena-Cruz, J.M.; Jorge, M.; Branco, J.; Cunha, V.M.C.F. (2012) "Bond between glulam and NSM CFRP laminates." Construction \& Building Materials, 40, 260-269.

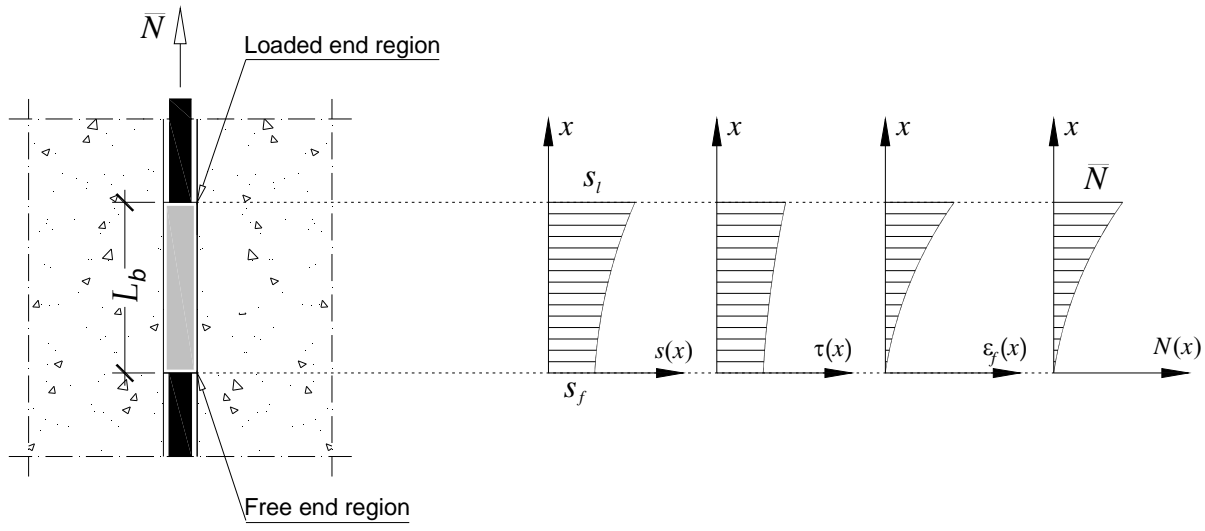

Fig. 6 - Entities in the analytical model. 
Sena-Cruz, J.M.; Jorge, M.; Branco, J.; Cunha, V.M.C.F. (2012) "Bond between glulam and NSM CFRP laminates.” Construction \& Building Materials, 40, 260-269.

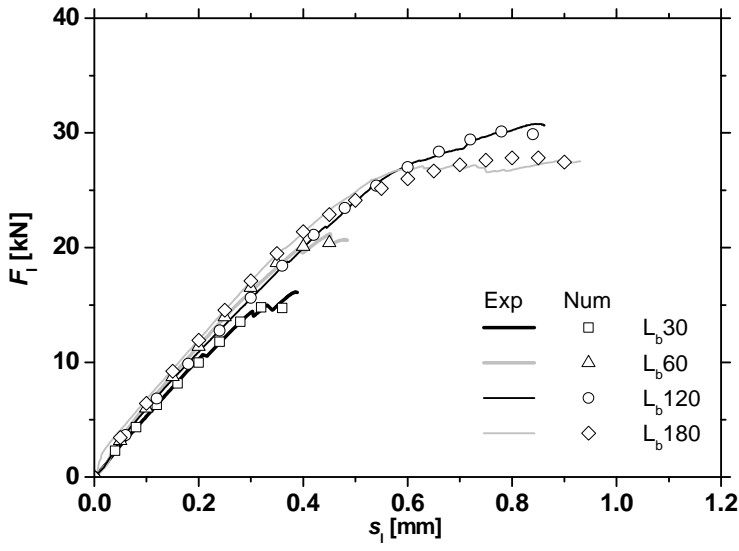

(a)

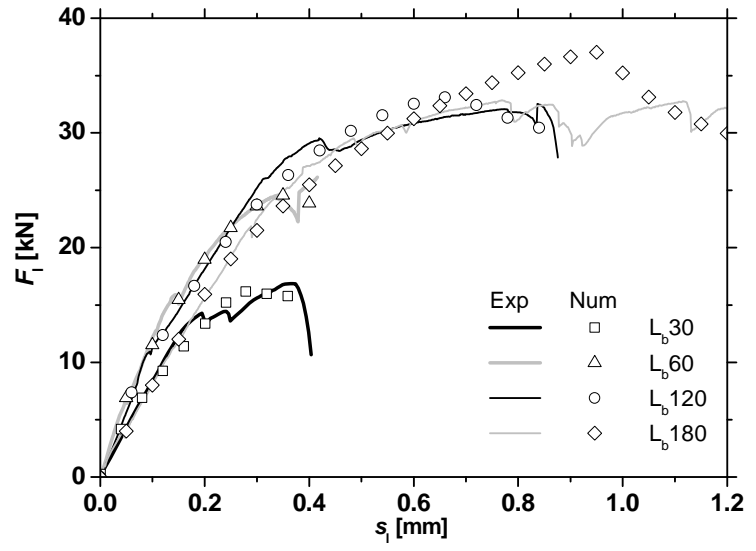

(b)

Fig. 7 - Pull-out force vs. loaded-end slip relationships obtained by inverse analysis for the: (a) direct and

(b) beam pull-out tests. 
Sena-Cruz, J.M.; Jorge, M.; Branco, J.; Cunha, V.M.C.F. (2012) "Bond between glulam and NSM CFRP laminates.” Construction \& Building Materials, 40, 260-269.

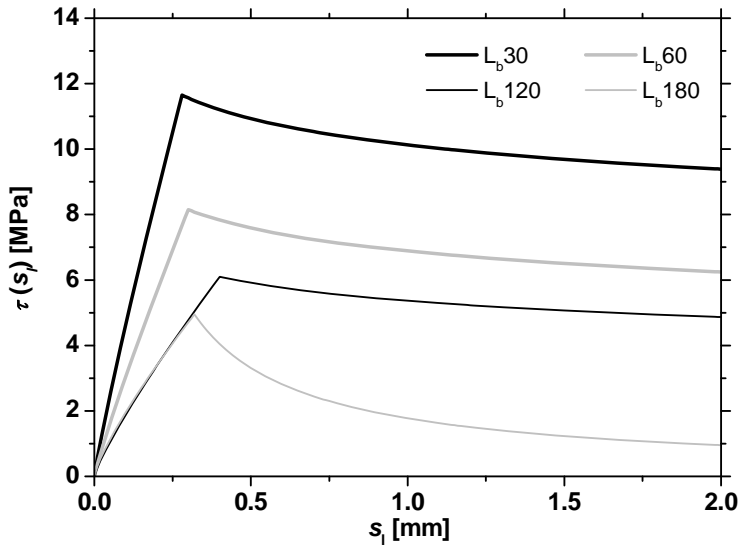

(a)

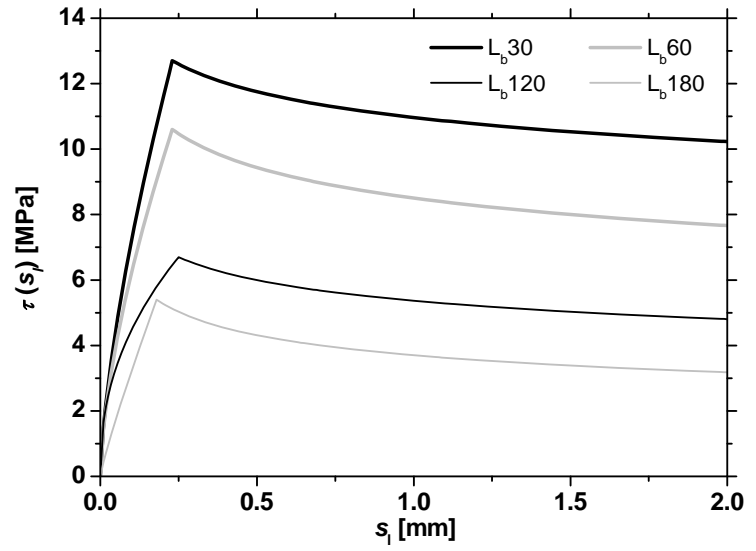

(b)

Fig. 8 - Variation of the local bond with the embedded length $\left(L_{\mathrm{b}}\right)$ for: (a) direct and (b) beam pull-out tests. 
Sena-Cruz, J.M.; Jorge, M.; Branco, J.; Cunha, V.M.C.F. (2012) "Bond between glulam and NSM CFRP laminates.” Construction \& Building Materials, 40, 260-269.

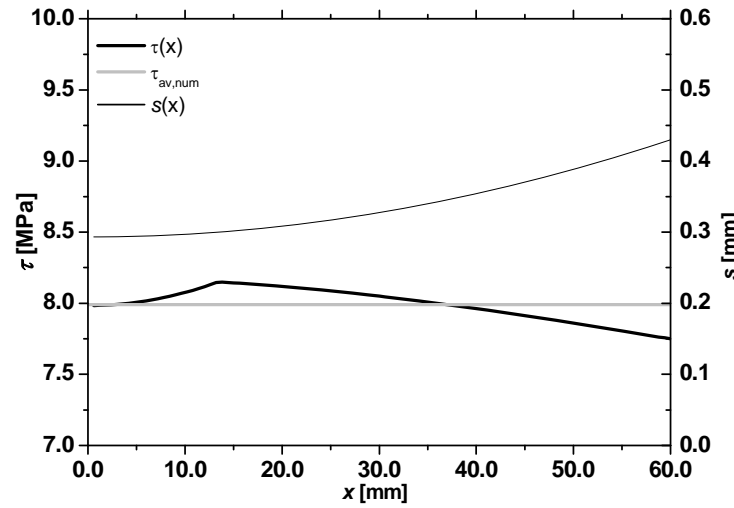

(a)

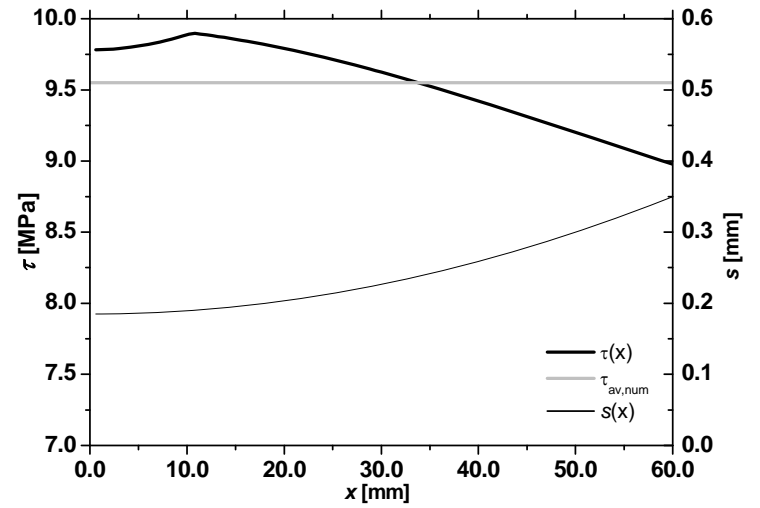

(b)

Fig. 9 - Variation of the bond stress, $\tau$, and slip, $s$, along the CFRP longitudinal embedded length $(x)$ at the maximum pull-out load for the series: (a) DPT_Lb60 and (b) BPT_Lb60. 
Sena-Cruz, J.M.; Jorge, M.; Branco, J.; Cunha, V.M.C.F. (2012) "Bond between glulam and NSM CFRP laminates." Construction \& Building Materials, 40, 260-269.

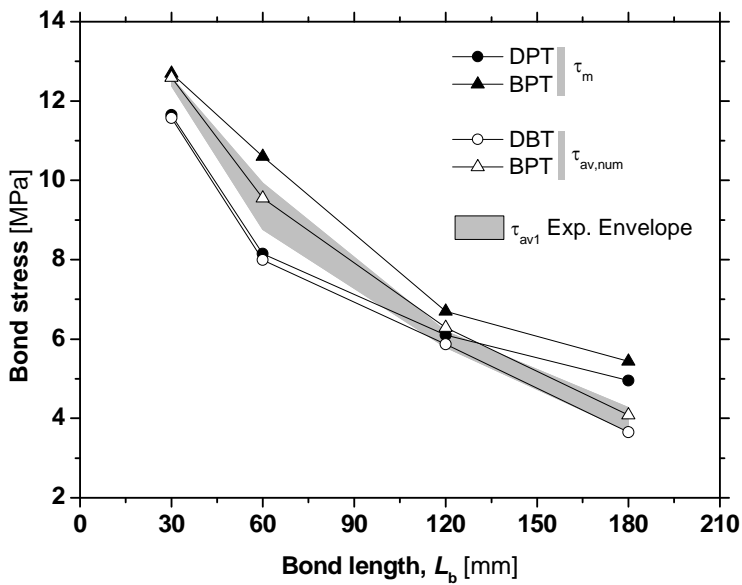

Fig. 10 - Bond length influence on the numerical average bond strength $\tau_{\text {av,num }}$ and numerical bond strength $\tau_{\mathrm{m}}$. 